\title{
Optimism in a time of uncertainty. Spinoza, Kant and the eternal peace
}

\section{Ingrid ROOS}

\section{University of applied Science Inholland, Diemen, the Netherlands}

\begin{abstract}
:
Aim: This article describes ideas of Enlightenment thinkers about the building of a democratic state with responsible and rationally thinking citizens. The article starts with the ideas of Spinoza, formulated in the seventeenth century, and will end in our time, where democracy is under threat.

Design/Research method: The article relies on professional publications, both within the fields of philosophy and political sociology.
\end{abstract}

Conclusions/findings: The study concludes that the optimistic expectations about the increase of democracy and the stability of democratic institutions in the world are no longer valid.

Originality/Value of the article: Recent developments in the political field in the western world make this optimism questionable.

Keywords: Philosophy, political sociology, democracy

JEL: Z18

Correspondence address: Ingrid ROOS, Anjelierenlaan 12, 2111BP Aerdenhout, The Netherlands. Email: viwi0@xs4all.nl.

Received: 30.09.2020, Revised: 14.11.2020, Accepted: 14.11.2020

doi: http://dx.doi.org/10.29015/cerem.892 
Ingrid ROOS

\section{Introduction}

This paper is born out of the conviction that democracy is too much seen as a thing that is self-evident and no longer as something that has developed over the last four centuries or so and which has constantly been discussed and fought over.

In this paper I will give a bird's eye view of the building up of democratic institutions and especially the role of the individual as a citizen of a state. The first part of the article leans on publications of philosophical thinkers, the second part is based on more recent studies in the field of the social studies in order to get some grip on the state of democracy in Europe and the United States.

I will start with Enlightenment thinkers such as Spinoza and Kant, who believe that you can, and should, build up a state in which the rights of the individual and the rights of states can be underpinned by the rule of law. Thinkers who also emphasize the responsibilities of the individual as a citizen. Here I will also discuss the ideas of Agnes Heller, who follows the ideas of Kant about morality. Heller highlights the responsibility of the individual as a citizen.

Recent developments in the political field in the western world make the idea of progress questionable. In the last part of the paper attention is paid to more pessimistic publications in the sociological field which point to the idea that democracy is a precious good that is under pressure in our days. In this part I try to get some grip on the causes of the decay of democratic values in our western societies.

The ideas of the Enlightenment thinkers about the future are based on an optimistic view of humanity. These thinkers, starting by Spinoza, see a bright future for mankind by building democratic states with responsible citizens who use rational thinking. However, the dilemma is that the human being is also an emotional being.

I will start with the ideas of Spinoza about emotion and reason. Spinoza, an early Enlightenment thinker, spoke about a state in which the individual as a citizen has the natural right of free reason and judgment: "no man's mind can possibly lie wholly at the disposition of another, for no one can willingly transfer his natural right of free reason and judgment, or to compelled to do so", he said (Spinoza 2004: 257). But Spinoza also knew the emotions of the individual and was afraid that too 
much freedom could be a danger for the peace of the state and the power of the rulers. How far can this freedom be allowed. Spinoza wrote his books in the seventeenth century, in a time when two great wars, the 80 year war and the 30 year war, had finished.

In the $18^{\text {th }}$ century Kant wrote his pamphlet Zum ewigen Frieden (Kant 1984). In this pamphlet he made it clear that war did not end by a cease-fire but that you could prevent a war by concluding a peace agreement. For Kant the foundation of peace between nation states had to be an peace agreement that was underpinned by the rule of law. Zum ewigen Frieden of Kant was published in 1795. The immediate cause was the peace between Prussia and France. After Kant there would be two World Wars in Europe.

Agnes Heller, a Hungarian philosopher, who lived from 1929 till 2019, started in her book A philosophy of morals (Heller 1990) with the ideas of Kant about morality. She formulated the question "how can a human being be a responsible citizen".

In the nineteenth and twentieth centuries the scientific, rational methods and explanations become more and more important. After the second World War we have built international institutions to enhance peace and to fight against hunger, sickness and war. In the world wide environmental crisis and in the world wide health crisis of Covid-19 we see that in the most part of the Western world governments make use of scientific methods to fight against the damaging influence of these crises.

According to modern thinkers such as Fukuyama and Pinker the world is better off with the ideas of reason, science and humanism. Pinker gives in his book Enlightenment now (2018) a lot of charts to show the progress of humankind in the fields of medicine, hunger, education, equality and so on. But will people agree with him and will the reason win of the emotion? 
Ingrid ROOS

\section{Reason and emotion by Spinoza}

The time when people started to think about a brighter future of mankind was the time that Jonathan Israel $(2001,2019)$ calls the Radical Enlightenment. Jonathan Israel situates that time after 1650. The influence of the church was diminishing and science, particularly the natural sciences, flourished. A process of rationalization and secularization had set in.

A highly important thinker of that time is, according to Jonathan Israel, Benedictus Spinoza, who was born in Amsterdam in 1634. Spinoza described the human being as a part of Nature gifted with reason and emotions.

The Ethics, written by Spinoza and published after his death in 1677, has as a subtitle: written in a geometrician style. Spinoza uses definitions, axioma's and propositions to make clear what he will postulate. Spinoza is a rationalist, a builder of a system who uses the deductive method. Spinoza believed that "only deduction from axiomatic principles delivered moral, political, religious and social truths, and that a desirable society was possible only if designed and enforced by reasoning individuals", as we read in Gullan Whur (2000: 133). Out of these general laws of nature Spinoza deduced, as he says: "those natural laws wherewith we conceive every individual to be conditioned by Nature, so as to live and act in a given way" (Spinoza 2004: 200).

That Spinoza chooses this method is not at all strange when we look at the fact that in the middle of the seventeenth century there was great progress in science, especially in mathematics and physics. We also know that Spinoza was acquainted with figures as Christiaan Huygens and other persons of the circle at Leyden University.

With his stance that Man is a part of Nature, Spinoza has definitely broken with the ideas of the Middle Ages of a transcendent and sovereign acting God and an individual that has to seek after salvation of his soul. For Spinoza there was neither a sovereign acting God nor a goal in Nature. As Spinoza states in The Ethics: "this eternal and infinite Being which we call God or Nature, acts by the same necessity as that whereby it exists" (Spinoza 2001). 
The human being, as part of nature, is gifted with passions but also with reason. In the introduction of part IV of The Ethics, Spinoza describes, what he names "the bondage" of the human being: "for when a man is a prey to his emotions, he is not his own master, but lies at the mercy of fortune: so much so, that he is often compelled, while seeing that which is better for him, to follow that which is worse" (Spinoza 2001).

Spinoza discusses his ideas about reason in part $\mathrm{V}$ of The Ethics. In the introduction he says: "I shall therefore treat therein of the power of the reason, showing how far the reason can control the emotions, and what is the nature of Mental Freedom or Blessedness; we shall then be able to see, how much more powerful the wise man is than the ignorant" (Spinoza 2001).

According to Spinoza when we have a better understanding of our passions we will have more power to handle these passions.

That Spinoza sees the human passions also as a danger for the state can we read in the passages where he describes his view on the human being as follows: "But men are more led by blind desire, than by reason: and therefore the natural power or right of human beings should be limited not by reason, but by every appetite [instinctive desires necessary to keep up organic life - IR], whereby they are determined to action, or seek their own preservation" (Spinoza 2004: 292). For Spinoza, it was the natural right of every human being "to preserve themselves". And that means that "the natural right of the individual man is thus determined, not by sound reason, but by desire and power" (Spinoza 2004: 201). But when we live according to our passions we live amidst enmity, deceit and anger, so according to Spinoza, it is better to live according to the dictates of our human reason.

Therefore Spinoza had to handle in his political theory with a human being that was gifted with a capacity of reason on the one hand and on the other hand was driven by his passions; an individual that has the natural right to be free and has the right to preserve himself. How can this individual become a citizen?

When we look at the description that Spinoza gives of the best form of government it is good to know that Spinoza lived in the Dutch Republic. He grew up in Amsterdam, a city with trade as its main source of income. He was born in a family of Portuguese Jews. His family were also merchants and Spinoza himself was 
well acquainted with that part of life. He lived after the revolt of the Provinces of the Dutch Republic against Spain, a war that is known in history as the 80 year war. This war was for an important part a war of religion. During and after this revolt and the victory of the provinces, the state had the form of a republic with as representative a stadholder. The key concept of citizenship In this Republic was that the citizens should participate in the political process and had the moral obligation to pay taxes. Citizens thus bore a clear responsibility (van Zanden, Prak 2006).

In chapter XVI of the TTP (Tractatus Theologico-Politicus - A TheologicalPolitical Treatise) Spinoza speaks about the foundations of the state and the role of the citizens. According to Spinoza, men need each other and must come to an agreement to live together. But, for men to do that, desire cannot be their guide but they must be guided by reason and "will restrain any desire which is injurious to a man's fellows, that they will do to all as they would be done by, and that they will defend their neighbor's rights as their own" (Spinoza 2004: 203). Spinoza discusses in the TP (Tractatus Politico - A Political Treatise) the idea of a democracy; the idea that an individual hands over power to a political body and citizens "have a right to vote in the supreme council and to fill public offices" (Spinoza 2004: 385). For "in fact, the true aim of government is liberty" (Spinoza 2004: 259).

However, Spinoza makes two statements: first the idea that an individual can abdicate the right of free action to the state but not the right to free reason and judgment. Spinoza pleaded for freedom of philosophical speculation and of religious belief. He saw this freedom as "absolutely necessary for progress in science and the liberal arts" (Spinoza 2004: 261). About this freedom Spinoza poses the question: "how far such freedom can and ought to be conceded without danger to the peace of the state, or the power of the rulers" (Spinoza 2004: 258)

The second idea is that action in obedience to orders of the state does not make a man a slave. This is the case when the object of the action is the good of the state. Spinoza has to reconcile obedience to the orders of the state and the natural right of an individual to be "a free man".

Spinoza had trust in a democracy and he stated: "In a democracy, irrational commands are still less to be feared: for it is almost impossible that the majority of a 
people, especially if it be a large one, should agree to an irrational design" (Spinoza 2004: 206).

In the TTP and TP Spinoza describes his ideas about the state and the role of the citizens. Important in this description is the role of the citizen as a free man gifted with reason. This free man is not fit for citizenship. But, as Spinoza formulated: "For men are not born fit for citizenship, but must be made so" (Spinoza 2004: 313).

And although the human being was a part of Nature and was not in the possession of a free will, man could be free of the power of church and religion. For the future science and reason had to be the leading principles of mankind.

\section{Kant and the eternal peace}

Immanuel Kant wrote in 1784 An answer to the question: What is Enlightenment? (Kant 1784a). According to Kant is "The Enlightenment the humanbeing's emergence from his self-incurred minority". In this article Kant argues that the public use of one's reason must always be free. That public use of reason alone can bring about enlightenment among human beings. An enlightenment that can be reached only slowly. It is clear that Kant not strives for a revolution. A revolution will not bring a true reform in one's way of thinking, according to Kant. Jonathan Israel poses: "Kant defends and justifies Enlightenment as a continuing program of moral advancement and general amelioration while deferring to the princes and simultaneously endorsing the general principles of the American and French revolutions" (Israel 2019: 597). Kant pleaded for a republican form of the state.

An important point for Kant was the involvement of an much wider circle of citizens by the government. Every man should not only have the possibility but have the duty to give his opinion. As he states "It is because of laziness and cowardice that so great a part of humankind, after nature has long since emancipated them from other people's direction nevertheless gladly remains minor for life, and that it becomes so easy for others to set themselves up as their guardians". The motto of Kant is "Dare to be wise" (Kant 1784a). 
The idea of the "public opinion" originated in the eighteenth century. The word "public opinion" we find for the first time in the Oxford Dictionary in 1781. The expression was used by Edmund Burke in his speech to the electorate (voters) in Bristol. In France the expression "public opinion" we found already in the middle of the eighteen century. In Germany it was Kant who introduced the idea of the public opinion as an important factor in politics, as Jürgen Habermas describes in his book Strukturwandel der Offentlichkeit (Habermas 1962). Kant argued that publicity was a means to bridge the gap between politics and morality. The public opinion has the possibility to bring morality in politics. Morality has here the notation of reason, the power of judgment. The citizen who was enlightened and could give his opinion was the citizen that reads books and was present at discussions in salons. For Kant these cultural traits were not the only ones that were necessary. To be an enlightened citizen you also need a social position and have an earning; so children, women and wage laborers could not been enlightened persons.

Kant himself gave his opinion about the relation between politics and morality in his pamphlet Zum ewigen Frieden. In the epilogue of this pamphlet, written by Rudolf Malter, we can read: "Gewährung und Wahrung des Friedens ist Sache der Politik; Politik jedoch, die sich allein auf ihre pragmatischen Mittel verläst, verfehlt den Frieden; sie geht auf ihn zu, wenn sie sich unter Grundsätze stellt, die aus reiner praktischer Vernunft, aus der »ursprünglichen moralischen Anlage in uns« stammen: Immanuel Kants berühmter Entwurf »Zum ewigen Frieden« setzt auf die Politik, die dadurch, dass sie sich der Idee des Rechts unterordnet, den Frieden unter Menschen ermöglicht" (Kant 1984: 69). ${ }^{1}$

"The conditions needed for mankind to reach the common goal of »perpetual peace« were the politicization of all nations, leading to fraternity of all republicans, autonomy of every state, and isonomia (political equality) of all states. Until then war between states remains inevitable" (Israel 2019: 609). These are, according to

\footnotetext{
1 "To start and maintain peace is a task of politics; politics, however, that is only grounded in pragmatism, fails peace; peace will only been reached when the peace is based on "praktische Vernunft «, on the origin of morality in ourselves". Immanuel Kant's well known pamphlet Zum Ewigen Frieden refers to politics that is based on the idea that only politics that is bound by the law brings peace among people" [translation - IR].
} 
Kant, the most important conditions for eternal peace. Coercion cannot longer been exercised by the person of a ruler but it is only the ratio that has power; "das einzig Vernunft Gewalt hat" ("that only reason has power").

Eternal peace could be very difficult to reach but Kant was optimistic about the future.

In Idea for a Universal History from a Cosmopolitan Point of View, a pamphlet that Kant wrote in 1784, he says: "Whatever concept one may hold, from a metaphysical point of view, concerning the freedom of the will, certainly its appearances, which are human actions, like every other natural event, are determined by universal laws. However obscure their causes, history, which is concerned with narrating these appearances, permits us to hope that if we attend to the play of freedom of the human will in the large, we may be able to discern a regular movement in it, and that what seems complex and chaotic in the single individual may be seen from the standpoint of the human race as a whole to be a steady and progressive though slow evolution of its original endowment" (Kant 1784b).

\section{Agnes Heller}

When Agnes Heller, a Hungarian philosopher speaks about Kant, she describes him as a thinker of morality. Heller also speaks about morality. She doesn't speak about a universal law that determined human actions, but she focusses in a more practical way on the responsibility of the person. Especially the modern person who lives in a contingent world, a world without clear roles and clear destinies. In her book A Philosophy of Morals she speaks about "the modern age which has invented the great narratives of our own (historical) determination and self-determination" (Heller 1990: 125). Besides these great narratives there is also the obligation for a person to be responsible. To be responsible means in this context to be not only responsible for your personal life but also for the common good.

Heller herself, born in 1929 and died in 2019, lived under a totalitarian communist regime. Later on she departed to New York; there she held the Hannah 
Arendt chair for 25 years. One of her topics is what it means to live as an individual in a totalitarian state. She asks how it is possible to make an connection between the institutions of the state and the ideas of morally engaged common people (Heller 1990: 125). She seeks the answer in the fact that contingency fill us with anxiety but only as long as we fail to meet our true historical condition.

Agnes Heller shows us that there is not only a story to tell, a story of a brighter future, but that there is also a personal obligation. The obligation to be a responsible person. In a situation of contingency responsible persons can make a difference. As Heller says: "Although everything that is could have happened otherwise, it is more than mere chance, for there are people who have transformed certain possibilities into realities while other people have failed to do so" (Heller 1990: 129).

\section{Science and optimism}

In the nineteenth century we see a drive by the elite in the Netherlands to make higher education affordable also for the middle class. It was van Vloten ${ }^{2}$ who worked for higher education that should be affordable for a greater part of the population, including the children of middle class people. It was also the time that in many countries in Europa compulsory education was introduced. It was not only reading and writing that had to be learnt also behavior and the cultural norms were involved, such as the norms of purity (cleanliness) and regularity. Ali de Regt (1984, 2015), a sociologist, speaks in her book about a civilization offensive. She describes the changes in the situation of the labor class and the beginning of social legislation. The sociologist Norbert Elias (1982) points to the increasing interdependence of men and the changes in the society. Auke de Woud (2015) speaks about the old and the new civilization and the many technical inventions. It was a time in which the old fashioned civilization changed in a great speed. There were people who were optimistic about the new world in which welfare should rise in a spectacular way. But there was also a part of people who saw in a book as Oswald Spengler's (2017,

\footnotetext{
${ }^{2}$ For bibliographic material on Johannes van Vloten, see https://www.dbnl.org/auteurs/auteur.php?id=vlot002.
} 
first published in 1918), Untergang des Abendlandes, their pessimistic view on the changes confirmed.

At the end of the century we see also the beginning of secularization in the Netherland and in other countries in Europe. Van Vloten propagated the ideas of Spinoza in the Netherlands and emphasized the autonomy of the human being. More and more new groups came on stage; first the males, later on, in the beginning of the twentieth century also females get the right to vote and to be represented in politics. Besides the awakening of groups to stand for their rights and to be responsible for their own community and their own fate, another process became more and more important: the influence of science on society.

Also at the end of the nineteenth century we see the blossoming of the scientific methods, not only in the natural sciences but also in the social sciences. The sociologist Max Weber (1864-1920) speaks about the "Entzauberung" of the world because of a process of intellectualization and rationalization. He saw rationalization in the realm of religion where the magical aspect was displaced by a more rational relation between man and the divine. Also in the sphere of law Weber documented "a course from the personalized dispensing of justice by wise leaders and elders, to the codified, rationalized, and impersonal justice of the modern world" (Coser 1971: 233). He was afraid that mankind in the future would live in an iron cage of his own making (Coser 1971: 233). But Weber also saw that rationalization and bureaucratization of the world was inescapable and gave man an unprecedented domination over the world of nature.

After the second World War the number of young people that started academic education surged. The trust in science was huge and a career as an academic was a dream of a lot of young people. Scientific methods and rationalization of all sort of processes became not only common in the natural sciences but also in the social sciences. 


\section{Disconnection and discontent}

After the second World War there were a lot of initiatives to make the world more stable by building global institutions. The idea was that these global institutions with voting rights for the states which participate in these institutions, would provide a basis for peace and development. The greatest player in these institutions is the United States of America. The United Nations, that has its headquarter in New York City, is an intergovernmental organization that aims to maintain international peace and security, took effect on 24 October 1945. The United Nations had fifty member states at its founding. Nowadays there are 193 member states. As early as 10 December 1948 the "Universal Declaration of Human Rights" was accepted. Thereafter more and more international institutions, affiliated to the United Nations, were erected as, the WHO, the WTO, IMF, the World Bank, the International Court of Justice and the IPCC (Intergovernmental Panel on Climate Change). The United Nations is the successor of the League of Nations that formally came into being on 10 January 1920.

After the Second World War more unity in Europa also started when, in the 1950s, six core states, Belgium, France, Italy, Luxembourg, the Netherlands and Germany, founded the European Communities as a predecessor of the European Union, which nowadays consists of 27 countries. A candidate of this Union has to meet the Copenhagen criteria, which require a candidate to have a democratic, freemarket government together with the corresponding freedoms and institutions, and respect the rule of law.

In the first decades after the end of the Second World War an optimistic idea began to spread: the idea that freedom and prosperity for all could be reached in the globalized world of the nearby future. The question is: is this a correct view on the history of man?

In the late 90s of the twentieth century there were writers (Castells, Putnam, Fukuyama) who pointed already to a decline of these feelings of progress and noted a change in the mood of people. Castells, a Spanish born sociologist, saw in the sixties and seventies of the twentieth century the beginning of a transformation in the society. He points to the following processes the information technology 
revolution, the economic crisis of both capitalism and statism (concentration of economic controls and planning in the hands of a highly centralized government often extending to government ownership of industry) and the blooming of cultural social movements such as libertarianism, human rights, feminism, and environmentalism. Castells painted the development of a global and capitalist economy and an increase of social inequality and polarization. In his conclusion at the end of volume III of his trilogy End of Millennium (2000: 390) says: "The dream of the Enlightenment, that reason and science would solve the problems of humankind, is within reach. Yet there is an extraordinary gap between our technological overdevelopment and our social underdevelopment".

Especially American scholars have a pessimistic view on the future at the moment. But also in Europe democratic institutions are under threat as publications of Freedom House show. Freedom House, a think tank that is founded on the core conviction that freedom flourishes in democratic nations where governments are accountable to their people, as we can read on the website, sees nowadays dangers for the core values of democracy. The think tank "sees attacks by elected leaders on democratic institutions, as there are - the press, independent judiciary, and anticorruption agencies - and on the rights of minorities and migrants". Freedom House has published a report, titled A Decade of Democratic Deficits. According to Freedom House net declines in Democracy scores in Europe and Eurasia have consistently outweighed net gains in the last ten years.

Fukuyama points in his book Political Order and Political Decay to the decay of the political institutions in the United States and the judicialization of the system. "The United States has returned to being a state of »courts and parties «" (Fukuyama 2014: 470). But it is not only the political institutions that fail. In his book he also describes the decline of the American government. "The federal government has become a destination of last resort for (young people wanting to make) a difference" (Fukuyama 2014: 460). Twenty two years earlier Fukuyama was a lot more optimistic about liberal democracy and only to the progress of humankind. In his book The End of History and the Last Man he points not the fall of the Berlin Wall, but also to the collapsing of authoritarian states in Southern Europe and the forming of democratic states in Latin America. But in his book Political order and political 
decay he says: "There is no automatic historical mechanism that makes progress inevitable, or that prevents decay and backsliding. Democracies exist and survive only because people want and are willing to fight for them" (Fukuyama 2014: 548).

About the political institutions in the United States recently an article was posted on the site of Huffington Post: “The GOP is very much Trump's Party, Poll shows" by Ariel Edwards-Levy (2020). More Trump voters said they were loyal to President Donald Trump than they were to the Republican Party. 49\% of Republican and Republican leaning independents who voted for Trump in 2016 said they consider themselves more supporters of Trump than of the Republican Party. Just $19 \%$ said they were more supporters of the party, with another $28 \%$ saying they were supporters of both. The poll consisted of 1000 completed interviews conducted from August 24 to August 26 among U.S adults.

Another way to look at the changing tide is to look at society and the ties between people. Putnam investigates in his book Bowling alone (2000) trust and reciprocity as a trait of the American way of life in the second half of the twentieth century. He looks at the social trust in the American society. Putman asked questions as "How often do you read a newspaper?", "Are you interested in politics?" and "Do you think most people can be trusted or that you can't be too careful?". Putman found, moving along the line of the oldest generation toward the younger generations, "that each generation that had reached adulthood since the 1950 s has been less engaged in community affairs than its immediate predecessor" (Putnam 2000: 254). Moreover the older generations are steadily replaced by younger generations. Putman sees this "as the single most important explanation for the collapse of civic engagement over the last several decades" (Putnam 2000: 255). Putman published his book in 2000.

Steven Pinker is more optimistic about the future of the enlightenment ideas. Pinker points in his book Enlightenment now (2018: 340) to the findings of an exit poll that the most consistent predictor of Trump support was pessimism about the direction of the country, the workings of the federal government and the lives of the next generation of Americans. Pinker refers also to research by the political scientist Ronald Inglehart (2016), who found similar patterns, based on their analysis of 268 political parties in thirty-one European countries. The support for populist parties is 
strongest not from manual workers but from "petty bourgeoisie". Populist voters are older, more religious, more rural, less educated and more likely to be male and members of the ethnic majority (Pinker 2018: 340). The same pattern we can find among Brexit-voters. Inglehart concluded that supporters of authoritarian populism are the losers not so much of economic competition as well as cultural competition. Populism is an old man's movement, as Pinker says. Pinker mentions also another factor in the rising of authoritarian populism namely the fact that many people, also younger people, stay home on election day, as we have seen in the voting over the Brexit.

Also in the European Union the voter turnout in the elections for the European Parliament decreased each time after 1979 the first time you could vote for this Parliament. In 2019 the voters turnout increased by $8 \%$ and went above $50 \%$ for the first time since 1994, as statistics point out (European Parliament 2020).

When we see voting as a civic plight and you remember all the years of struggle to get voting rights for everyone, it is not a rational act to abandon that right.

Is the election of Trump as president of the United States and his idea of "America First" the end of the spreading of democratic ideals in the world and the building of international institutions.

Are the ideas of Kant, the belief and trust in global political institutions and the importance of a democratic state as painted by Spinoza foregone?

The other prominent idea of the Enlightenment was the use of science and scientific methods to make the world a better place to live in. When Spinoza gave a voice to these ideas he was fighting against superstition. Superstition was for him related with emotions. Science was the fruit of reason.

Popper (1977) who published his book The open society and its enemies in 1945 argued that the conflict between rationalism and irrationalism has become the most important intellectual, and may be the most important moral issue as well, of our time. Popper describes rationalism as an attitude of listening to critical arguments and learning from experience.

Popper also says that equality for the law is not a fact, but a politic decision and that "the choice for rationalism is a moral decision. Rationalism is tightly connected 
with the belief in the unity of mankind" (1977: 232). For Popper morality is inherent in his choice of modern science (1977: 240).

When we look at the world of our time we see a lot of problems but no or not enough political will to solve the many problems. Are we responsible persons at the moment that the scale of the problems is not our own nation or the nations around us but the problem is at a global scale. Are we the responsible person in the sense as Heller defines them?

Is men a rational being as Enlightenment thinkers believe that trust science and will handle according to the facts of scientific enquiry?

\section{Conclusion}

The ideas of the Enlightenment have a history of centuries. The Enlightenment thinkers saw in the reason the key for a brighter future. When we start by the Early Enlightenment in the $17^{\text {th }}$ century, we see that Spinoza saw a bright future for mankind when it was led by reason. For Spinoza it was reason that gives guidance to freedom and makes the building of state possible. Spinoza trusted in the possibility to make men fit for citizenship.

One century later it was Kant who described enlightenment as the human-beings emergence from his self-incurred minority. Also Kant saw a steady and progressive evolution toward a better future. Kant based his optimism also on a public use of reason. The Enlightenment is according to him a continuing program of moral advancement.

Heller does not speak like Kant about a steady and progressive revolution but about the responsibility of every person. Persons have the moral obligation to be responsible for the state they live in.

In the $19^{\text {th }}$ century we see a blossoming of scientific methods in natural and social sciences. In politics we see that not only the better off citizens but also the labor class males and the females get the right to vote. There was optimism about the future. After two World Wars there was a new elan to make the world stable and 
a better place to live in. Global institutions were erected. In Europa the European Union was founded. The dream of a better and a more peaceful world was not dead.

In our days there is a lot of uncertainty about the future of stable democracies. Scientists as Castells, Putnam and Fukuyama are concerned about the future of democratic institutions in the United States and other places in the world. Also there are signs of a steady diminishing in civic engagement and social trust in the societies where we live in.

At this moment we see many big crises in the world, a health crisis, a climate crisis and the coming of illiberal democracies as in Hungary, Poland and Latin America. There are sparks of hope with women in Belarus who fight for fair elections and women in Pakistan who fight for their rights to go freely on the streets. Also we saw young people fighting for measures to stop climate change.

When we look at the role of the citizen in the historical process, we see that in democratic states more and more people, not only men but also women, not only rich and well educated people but all people have at least get voting rights. Responsibility as a citizen refers not only to voting rights but also to morality, to make the choice to be a responsible person, as Heller argued. Every person should have the possibility to say what his opinion is, according to Spinoza that is the right of the free person, with Kant it is more or less an obligation.

A democratic state is not something that is and shall always be there. This state is the end of a long historical process of progress and decline. But decline is not inevitable.

\section{References}

Castells M. (2000), The information age. Economy, society and culture, vol. III: End of millennium, 2nd ed., Blackwell Publishers, Oxford 2000.

Coser L.A. (1971), Masters of sociological thought. Ideas in historical and social context, Harcourt Brace Jovanovich, Inc., New York, Chicago, San Francisco, Atlanta.

Elias N. (1982), Het Civilisatieproces, sociogenetische en psychogenetische onderzoekingen, deel 1 en 2 Aula, Uitgeverij Het Spectrum, Utrecht, Antwerpen.

European Parliament (2020), 2019 European election results, https://www.europarl.europa.eu/electionresults-2019/en/turnout/ [17.12.2020]. 


\section{Ingrid ROOS}

Fukuyama F. (2012), The end of history and the last man, Penguin Books, London.

Fukuyama F. (2014), Political order and political decay, Profile Books LTD, London.

Gullan-Whur M. (2000), Within reason. A life of Spinoza, Pimlico, Random House, London.

Habermas J. (1962), Strukturwandel der Offentlichkeit, Hermann Luchterhand Verlag GmbH, Neuwied, Berlin.

Heller A. (1990), A philosophy of morals, Basil Blackwell, Cambridge, MA.

Edwards-Levy A. (2020), The GOP is very much Trump'sParty, Poll shows, Huffington Post, https://www.huffpost.com/entry/poll-republican-party-trump_n_5f4bfb18c5b697186e37936a,

[10.09.2020].

Inglehart R. (2016), The danger of deconsolidation. How much should we worry?, "Journal of Democracy”, vol. 27 no. 3, pp. 18-23.

Israel J.I. (2001), Radical Enlightenment. Philosophy and the making of modernity 1650-1750, Oxford University Press, Oxford.

Israel J.I. (2019), The Enlightenment that failed. Ideas, revolution, and democratic defeat, 1748-1830, Oxford University Press, Oxford.

Kant I. (1784a), An answer to the question: What is Enlightenment?, Immanuel Kant: Ethics Reference Archive, https://www.marxists.org/reference/subject/ethics/kant/index.htm [01.12.2020].

Kant I. (1784b), Idea for a universal history from a cosmopolitan point of view, Immanuel Kant: Ethics Reference Archive, https://www.marxists.org/reference/subject/ethics/kant/universal-history.htm [01.12.2020].

Kant I. (1984), Zum ewigen Frieden, Philipp Reclam Verlag, Stuttgart.

Pinker S. (2018), Enlightenment now, Penguin Books, Random House, London.

Popper K.R. (1977), The open society and its enemies, vol. 2: Hegel \& Marx, Routledge \& Kegan Paul, London, Henley.

Putnam R.D. (2000), Bowling alone. The collapse and revival of American community, Simon \& Schuster, New York.

de Regt A. (1984), Arbeidersgezinnen en beschavingsarbeid. Ontwikkelingen in Nederland 1870-1940, Boom Meppel, Amsterdam.

De Regt A. (2015), Beschavingsoffensief (civilising offensive): from sociological concept to moral appeal, "Human Figurations", vol. 4 no. 1, http://hdl.handle.net/2027/spo.11217607.0004.103 [17.12.2020].

Spengler O. (2017), Der Untergang des Abendlandes - Umrisse einer Morphologie der Weltgeschichte, Anaconda Verlag, Köln. 


\section{OPTIMISM IN A TIME OF UNCERTAINTY. SPINOZA, KANT AND THE ETERNAL ...}

Spinoza de B. (1979), Ethica. Wereldbibliotheek, Amsterdam.

Spinoza de B. (2001), The Ethics (Ethica Ordine Geometrico Demonstrata), transl. from the Latin by R.H.M.Elwes, www.gutenberg.org/files/3800/3800-h/3800-h.htm [01.12.2020].

Spinoza de B. (2004), A theologico-political treatise and a political treatise, Dover Philosophical Classics, Dover Publications, Inc., Mineola, New York.

van der Woud A. (2015), De Nieuwe Mens, de culturele revolutie in Nederland rond 1900, Prometheus, Bert Bakker, Amsterdam.

van Zanden J.L., Prak M. (2006), Towards an economic interpretation of citizenship. The Dutch Republic between medieval communes and modern nation-states, "European Review of Economic History", vol. 10 no. 02, pp. 111-145. 